\title{
Second National Leprosy Congress, Buenos Aires, 1968
}

The Second National Leprosy Congress, Argentina, was held in the National Medical Academy in Buenos Aires from 6 to 10 November, 1968 . A very representative body of participants from all over the country, and including specialists in all aspects of leprosy-clinical, laboratory, rehabilitation-took part in Panel discussions. A comprehensive Report on the conclusions reached in these Panels was issued at the close of the Congress.

Panel 1 explored the dimensions of the leprosy endemic in different parts of the country, and recommended measures for control, such as the co-operation of private practitioners, notification and registration of all leprosy patients, and widespread "prophylactic action". It was suggested that a national fund be established to provide money for research into leprosy, and that private agencies as well as official bodies should contribute.

Panel II considered the modern treatment of leprosy, and concluded that the sulphones were still the drugs of choice, but that the long-acting sulphonamides, the rimino-phenazine compound (B 663, Lampren), and thiambutosine also had a place in therapy. In lepromatous reaction, thalidomide, convalescent serum, ACTH, and B 663 were advocated if standard measures fail. It was held that specific treatment should be continued during lepromatous reaction.

Regarding prophylaxis, Panel III reviewed the accepted methods of control of leprosy transmission (such as early diagnosis, adequate ambulatory treatment, medical supervision of patients and contact examination), and looked forward to the day when compulsory universal $B C G$ vaccination of infants would replace the present system of offering $\mathrm{BCG}$ only to contacts of leprosy sufferers. Limited research into chimioprophylaxis was recommended, with due regard to thedanger of drug-induced "iatrogenic phenomena". The role played by voluntary organizations in ensuring co-operation in any scheme for leprosy control was freely acknowledged.

Panel IV, which was devoted to consideration of the scientific aspects of leprosy-immunology, bacteriology and genetics-reviewed recent research in these fields, and suggested that similar work should be undertaken in Argentina if adequate financial support were forthcoming.

Panel V (physical, psychical, family and social rehabilitatıon) covered familiar but most important ground, and advocated the continued collaboration of all workers engaged in the anti-leprosy campaign, and the mobilization of all forms of educational aids to make the community aware of the importance of the leprosy endemic. The Panel recommended the abolition of "preventoria" and of the specific legislation concerning leprosy, so that the leprosy patient would be treated everywhere in the country like sufferers from any other slightly contagious disease.

\section{Journées Médicales de Dakar}

Leprosy was accorded a special place at the Dakar meetings this year, which were held in January (13 to 18), amid the usual galaxy of doctors and pharmacists from France itself and from French-speaking countries. Round Tables were held, under the genial presidency of General J. Languillon, on (1) the classification and pathogenesis of reactional states, and (2) leprous neuritis. Among the participants were Professors A. Basset, A. Carayon and R. Camain, and Dr. S. G. Browne. Histological evidence was presented showing the localization of damage in certain peripheral nerves in leprosy. 


\title{
Rehabilitation of the Disabled in Africa
}

\author{
Third Symposium, Lusaka, 1969
}

Kampala (1964), Addis Ababa (1966) and now Lusaka (Zambia) in 1969. This, the third Symposium sponsored by the Committee for Rehabilitation of the Disabled in Africa, held from 10 to 14 February, attracted medical and non-medical workers from many African countries interested in various aspects of the problem. Mr. Duncan Guthrie, the indefatigable Director of the National Fund for Research into Crippling Diseases, to whose initiative and enthusiasm these Symposia owe much, was Chairman.

Although leprosy did not figure in the programme to the extent that leprologists might deem to be commensurate with its importance as a major crippling disease in the continent of Africa, the discussions, findings and recommendations of the meeting are of interest to leprosy workers generally, and the experiences shared by those whose interests lie in reconstructive surgery, prostheses, epidemiology, footwear, and the care of paraplegics, will prove of future benefit to the leprologists who were privileged to participate.

Dr. Ray Foster, an orthopaedic surgeon working with the Seventh Day Adventist Mission in Zambia, presented a paper entitled "Surgical examination of the hands, face and feet of 562 leprosy patients". In addition to his work in Zambia, Dr. Foster visits Malawi from time to time to operate on leprosy patients at Malamulo Leprosarium. Prof. Roy Ebenezer, of the Christian Medical College, Vellore, South India, sent (to be read in his absence) a paper on "Eye lesions in leprosy".

The various recommendations of the Symposium may with advantage be studied by leprosy workers in other continents, as they see their own problems in the light of the considerable and increasing prevalence of deformity in the developing countries of Africa. We welcome the double insistence on prevention and training that was much in evidence during the deliberations of the Symposium.

We quote from the Symposium as follows:

"The Third Symposium on Rehabilitation in Af rica:

(8) Recommends that the Governments of the nations of Africa include in their plans for economic and social development measures to stimulate the prevention of disabling conditions, and programmes to initiate and to expand coordinated medical, vocational, social and educational services for disabled persons;

(9) Urges the United Nations Economic Commission for Africa to give early and detailed consideration to the problems of disability and to activities to encourage and assist Governments in the development of more adequate rehabilitation facilities;

(10) Expresses the hope that the United Nations, the International Labour Office, WHO, UNESCO, UNICEF and interested international non-governmental organizations will allocate additional resources to assist the Governments of the nations of Africa in the planning and development of rehabilitation facilities and services; and that Governments aiding the nations of Africa in their economic and social development will include support for projects to develop services for the disabled; that national non-governmental organizations will continue and increase their assistance in this field; and that all concerned will give careful attention to the co-ordination of their efforts;

(11) Suggests that, in view of the limited facilities in Africa for the training of personnel in rehabilitation skills, the Governments and organizations concerned consider the possibility of establishing wherever possible training centres on a regional basis.",

1)r. Luther Fisher, orthopaedic surgeon to the ALERT Project in Addis Ababa (The All-Africa Leprosy Rehabilitation and Training Centre), in reporting the Symposium, expresses the hope that leprosy will in the next (the fourth) Symposium be accorded the place on the programme commensurate with the personal and economic devastation that it causes in Africa. 


\section{Leprosy in Nepal}

The First Inter-country Leprosy Seminar-the first of its kind-was held in Kathmandu, Nepal, from 17 to 22 March, 1969, under the auspices of the Government of Nepal and the World Health Organization. The main purpose was to disseminate information about leprosy among the zonal medical officers of the government health service. Doctors were present from Afghanistan and Ceylon. Representatives of voluntary agencies with local experience of tackling leprosy were invited to be present as observers. The World Health Organization provided the services of Dr. P. N. Khoshoo and Dr. T'. Frank Davey, c.B.E., as consultants, together with Ir. R. Ignatovic, epidemiologist. Dr. Stanley G. Browne attended as an invited observer.

Royal interest was shown by the personal message of greeting sent by the King, and by the inaugural address given by Her Royal Highness Princep Shah, well-known for her interest in all that concerns the social welfare of the citizens of Nepal. Although it is less than 20 years since Nepal opened its frontiers to the outside world, the dimensions of the leprosy problem have been brought to official notice by the pioneering work of Missions and successive visits and reports of World Health Organization experts. It was thus fitting at this stage that a seminar should be arranged that would take account of the accumulated knowledge concerning leprosy prevalence, indicate the considerable gaps in this knowledge, and concern itself with the broad lines of leprosy control.

The WHO consultants gave most valuable didactic courses of instruction on various aspects of leprosy for the benefit of those who had had little opportunity for such study in the past, and some interesting contributions were made by Nepalese doctors and by a government Health Education Officer.

As foreshadowed in the inaugural address by Her Royal Highness, the social aspects of leprosy in Nepal claimed a considerable share of the attention of the participants. Notwith- standing the great difficulties of transport and communication, and the embryo nature of much of the medical service in this mountainous and developing country, it was the social and legal aspects of leprosy that appeared to pose the most urgent and the most intractable problems. Ingrained attitudes to leprosy that are compounded of fear and superstition are reinforced by discriminatory legislation surviving from an unscientific past. Compulsory segregation on diagnosis is still on the statute book, and the cost of maintenance of the 2 government leprosaria is a severe drain on the economy of the country, leaving little remaining for leprosy control work. Diagnosis or treatment of leprosy can be cruelly stigmatizing, exposing the victim to proceedings for divorce, to dismissal from employment, to forcible segregation and to various social disabilities. The participants in the Seminar were unanimous in their forcefully expressed opinion that the law be brought into line with that in forward-looking countries facing the same leprosy problem.

The prevalence of the disease was stated to be about $1 \%$ in several representative sample surveys that had been done. Further information was needed, particularly in some zones where the numbers of patients voluntarily coming forward for diagnosis suggested even higher prevalence rates. In addition to the special hospitals established by voluntary agencies for the care of leprosy patients, excellent pioneer surgical reconstructive schemes are in operation.

Various suggestions were put forward for the strengthening of the anti-leprosy campaign and its integration into the public health service, and also for the education of the public and the mobilization of goodwill among the citizens of this fascinating country. Nepal is in many ways making up for lost time in the speed and enthusiasm which its sons are manifesting in an effort to take the best of modern Western science and apply it to the urgent needs of the country.

S. G. BRownt 


\section{World Leprosy Day}

The 16th World Leprosy Day was observed on 26 January, 1969, in well over a hundred countries. Thanks to the peripatetic advocacy of its founder, Monsieur Raoul Follereau, governments and private individuals have been made aware of the plight of leprosy sufferers in their midst. Discriminatory laws and attitudes have been changed and practical service has been stimulated.

It is not too soon to start planning ahead now for the worthy celebration of the $17 \mathrm{th}$ World Leprosy Day on Sunday, 25 January, 1970.

\section{ALERT in Ethiopia}

At the Annual Meeting of Members of ALERT (the All-African Leprosy Rehabilitation and Training Centre) held in Addis Ababa on 28 March, 1969, the growth and development of the Project during the preceding 12 months was considered to be satisfactory. The following new members were welcomed: Netherlands Government Technical Aid and Deutches Aussatzigen-Hilfswerk e.V.

The service functions of ALERT, both at the Princess Zenebework Hospital, Addis Ababa, and in the rural control area, give evidence that the members of staff are pooling their diverse skills and experience for the specialized as well as the routine treatment of a great number of leprosy patients. For instance, over 2500 attend as out-patients at the central hospital, and 1486 are under treatment at 21 centres in the control area. As in other projects, case-finding is proving far from easy and rather expensive. The average prevalence rate in the limited surveys undertaken is of the order of $18 / 1000$.

Three courses of training have been offered during the year for students from outside Ethiopia and the prospects for the future are assured, now that teaching staff is available for the combined service-training functions that will continue to be a feature of ALERT. Higher courses are planned especially for doctors, physiotherapists, nurses and rural area supervisors. An augmented active interest of African governments, the World Health Organization, and Mission Boards in sponsoring suitable candidates would be welcome if the installations and resources of ALLERT are to be fully utilized as a training centre for the continent of Africa. An ambitious building programme, now under way, will provide increased in-patient accommodation and associated services. The practical interest of the Imperial Ministry of Public Health and the Haile Selassie I University is much appreciated.

\section{Film on Cockett's Operation}

Mr. Frank I. Tovey, O.B.F., CH.M., F.R.c.s., whose paper on "Reconstruction of the nose in leprosy patients" was published in Leprosy Review (1965) 36, 215, informs us that a film of the operation has been made. It is $8 \mathrm{~mm}$, and silent. Anybody wishing to borrow the film should apply to Mr. Tovey at: 47 Hill Road, Oakley, $\mathrm{Nr}$ Basingstoke, Hampshire. Mr. Tovey worked for some years at the Mary Calvert Holdsworth Memorial Hospital in Mysore City, India, where he devoted his surgical knowledge and skill to reconstructive surgery for leprosy patients. 


\section{ELEP Leprosy Control Project, Dharmapuri, Tamil Nadu (formerly Madras State, South India)}

The first Annual Report (1968) of this ambitious Project describes the initial spade-work undertaken by the Director, Dr. I. A. Susman, and the team he is at present engaging. The total population of the 4 Taluks in the district is nearing $1 \frac{1}{2}$ millions, with a density of 394 per square mile. The prevalence of leprosy is thought to be in the neighbourhood of $31 / 1000$, giving an estimated total of about 45,000 for the Control Project area. Of these, probably $20 \%$ are suffering from the lepromatous form of the disease. With the experience of the successful control measures adopted in a comparable milieu in Polambakkam and Pogiri, the Director should be able to plan his method of attack, so as to integrate leprosy control into the existing public health organization. Early detection of leprosy and early treatment for all leprosy sufferers throughout the district is the ultimate aim of the Project. After 5 years, it is expected that the Project, fully developed and embracing the whole area, will be handed over to the Indian Government.

So far, the great majority of patients now receiving treatment became known through voluntary reporting of suspicious signs. Examination of healthy contacts and of the general population has given only inappreciable resuits: the huge reservoir of undiagnosed and untreated leprosy remains.

Meanwhile, we follow with interest this experiment in international co-operation and goodwill, and express the hope that the Dharmapuri Project will serve as an example both to the philanthropically-minded and to those practically concerned with the deployment of the most economical and most effective measures of leprosy control in the great subcontinent of India and elsewhere.

\section{News and Personalia}

\section{NEW MEDICAL DIRECTOR OF FONTILLES}

Dr. Terencio de las Aguas has been appointed Medical Director of F'ontilles Leprosy Sanatorium, Spain. Well-known in international leprosy circles for his contributions to research through the journal Fontilles and for the papers he has given at various congresses, Dr. Terencio has been "medical resident" at Fontilles since 1953, and Assistant-Director since 1964. Under his able direction, the work at Fontilles itselfmedical treatment, surgical rehabilitation, diverse research projects, and teaching seminarsand throughout Spain should not only maintain the traditions established by his predecessors, but stimulate effective measures of leprosy control in a country where the endemic problem is far from negligible.

\section{MEDECIN-GENERAL JEAN LANGUILLON}

We offer our sincere congratulations to MédecinGénéral Jean Languillon on his being nominated Chevalier de l'Ordre National de la République du Sénégal. The announcement of the award was made, and the decoration presented, at an evening reception given during the VI Journées Médicales de Dakar on 17 January, 1969. In addition to his therapeutic researches at Bamako, Mali, Général Languillon has been closely identified with the work of the Pavillon de Malte for leprosy patients in Dakar and the teaching of medical students in the mixed faculty of Medicine and Pharmacology of the University of Dakar. 